Article

\title{
Designing the National Network for Automatic Monitoring of Water Quality Parameters in Greece
}

\author{
Angeliki Mentzafou *(D), Yiannis Panagopoulos $\mathbb{D}$ and Elias Dimitriou $\mathbb{D}$ \\ Hellenic Centre for Marine Research, Institute of Marine Biological Resources and Inland Waters, \\ 16604 Anavissos Attikis, Greece; ipanag@hcmr.gr (Y.P.); elias@hcmr.gr (E.D.) \\ * Correspondence: angment@hcmr.gr; Tel.: +30-2291076349
}

Received: 21 May 2019; Accepted: 21 June 2019; Published: 25 June 2019

check for updates

\begin{abstract}
Water quality indices that describe the status of water are commonly used in freshwater vulnerability assessment. The design of river water quality monitoring programs has always been a complex process and despite the numerous methodologies employed by experts, there is still no generally accepted, holistic and practical approach to support all the phases and elements related. Here, a Geographical Information System (GIS)-based multicriteria decision analysis approach was adopted so as to contribute to the design of the national network for monitoring of water quality parameters in Greece that will additionally fulfill the urgent needs for an operational, real-time monitoring of the water resources. During this cost-effective and easily applied procedure the high priority areas were defined by taking into consideration the most important conditioning factors that impose pressures on rivers and the special conditions that increase the need for monitoring locally. The areas of increased need for automatic monitoring of water quality parameters are highlighted and the output map is validated. The sites in high priority areas are proposed for the installation of automatic monitoring stations and the installation and maintenance budget is presented. Finally, the proposed network is contrasted with the current automatic monitoring network in Greece.
\end{abstract}

Keywords: river waterbodies; freshwater vulnerability; pressures; GIS-based multicriteria decision analysis; Analytic Hierarchy Process

\section{Introduction}

Abundant and high quality water resources have always been linked to human survival and socioeconomic development [1], while the access of people to safe freshwater has commonly risen conflicts [2]. A water quality variable is any physical, chemical, or biological property that influences the suitability of water for natural ecological systems or the use by humans, and the term water quality is linked to the suitability of water for a particular purpose [3]. The presence/absence or concentration level of specific physico-chemical and microbiological variables determine the quality of water, while water quality indices are often used to describe the condition of water derived from a series of noncommensurate observed facts and measurements [4]. Water quality indices can be used as a tool to communicate water quality information to the public, regulatory agencies, and stakeholders $[4,5]$, and are often used in freshwater vulnerability assessment [6]. Freshwater vulnerability is a product of both biophysical and socioeconomic factors, and can be defined as "the susceptibility of a system to damage, as a function of exposure to external forces, sensitivity of the system, and the ability of the system to respond" [7].

Historical observations of water quality variables provide the irreplaceable means for understanding the behavior of water resource systems, while real-time data are essential for assessing their current status and making short-term predictions concerning the water availability and the associated risks. Real-time water monitoring through automatic stations provide fundamental 
data for understanding aquatic ecosystem processes and impacts from anthropogenic activities [8]. High temporal resolution data enable the detection of both short-term events and long-term changes [9], and thus become increasingly necessary when studying the impacts of climate change on water quality due to changes in nutrient transfer dynamics [10]. Many of the existing automatic monitoring systems that provide real-time, continuous, reliable, and low-cost measurements [11], focus on the estimation of pollution pathways, assessment of the ecological status and early detection of pollution or flood/drought events [12,13].

The design of water quality monitoring programs has always been a challenge due to the many variables that need to be included [14]. Additionally, water managers must respond to new challenges and to keep up with the latest developments and trends concerning the water quality research and monitoring, such as the chemical mixtures [15], microplastics [16], the management practices [17,18], recent legislation, and, especially, the goals set by the Water Framework Directive (WFD 2000/60/EC) of the European Community (EU) [19], but also new tools such as effect-based tools (bioassays, biomarkers [20,21]), remote sensing [22], advances in monitoring sensors (e.g., nanophotonic biosensors [23] and optical sensors [24]), and automation technology system [25].

A successful environmental water quality monitoring program relies on the following main elements [26]; identification of the monitoring objectives, national and EU institutional setting, preliminary surveys, monitoring design (selection of representative sampling sites and frequencies, and water quality variables), adjustment to budget and operational restrictions, design of field protocols, field monitoring operations, laboratory activities, quality-assurance procedures, data management and analysis, and product development and reporting. Based on the review concerning the design of water quality monitoring networks, there is a variety of methodological approaches, e.g., statistical, multicriteria decision-making, entropy-based and fuzzy logic approaches, or a combination of the above (e.g., [27-34]). These methodologies are usually difficult to be applied by not qualified personnel and require long and reliable time-series [35]; therefore, they are usually used in evaluation and optimization of an existing monitoring program, rather than in the initial design of water quality monitoring network.

In Greece, there is lack of a representative automatic monitoring network for measuring the quality of waterbodies, although systematic water sampling is carried out within the framework of the National Water Monitoring Network of the WFD 2000/60/EC, under the supervision of the General Secretariat of Water of the Ministry of Environment and Energy [36]. Although the purpose of the WFD sampling is surveying both the quantitative and qualitative status of the water resources of Greece on an operational basis, its current design and functioning is mostly based on in situ observations at seasonal frequency, thus providing information of the overall environmental annually. Therefore, this system mainly focuses on the design and evaluation of water management and restoration measures on a long-term basis, but cannot fulfill the urgent needs for operational, real-time monitoring of the water resources at the national level.

In the present effort and under the research project "Hellenic Integrated Marine-Inland waters Observing Forecasting and offshore Technology System, HIMIOFoTS", the existing status of the current network of automatic quality stations in Greek river waterbodies is presented, and, based on the pressures and importance of the latter, the priority areas across the country to expand this network are indicated, proposing the installation and operation of automatic, telemetric stations in important sites from environmental and socioeconomic perspectives. The designation of areas of increased need for monitoring was performed with a GIS (Geographical Information System)-based multicriteria decision analysis (GIS-MCDA) approach that is cost-effective and easily applied and does not require qualified personnel and access to extended information. 


\section{Materials and Methods}

\subsection{River Monitoring in Greece}

The current status of hydro-environmental information in Greece is rather poor, as the country is lagging significantly behind its EU partners in developing monitoring infrastructures to meet the challenges induced by the increase in hydrologic and water quality pressures as well as by the relevant EU requirements [37]. According to the EU recommendations related to the implementation of WFD Program of Measures (PoMs), Greece has, among others, to make its National Monitoring Programme (NMP) fully operational and update the River Basin Management Plans (RBMPs) based on robust and consolidated data [37]. In fact, many existing automatic monitoring stations which could feed the above tasks with valuable data are abandoned, while others do not operate appropriately due to inappropriate siting, inadequate maintenance or because of the use of outdated measuring technologies. Furthermore, their data are often temporally fragmented and hardly accessible, leading to the mismanagement in many Greek surface waterbodies. Installing operational systems with modern equipment (e.g., telemetric stations) is not centrally coordinated but few sparse efforts are carried out by various ministries, educational, and research institutes or local water management authorities, being subject to the limited spatial extent and duration of the associated individual projects.

Despite the above shortcomings, the upgrade and expansion of existing water monitoring infrastructures is a pan-European goal as water resources quantity and quality monitoring has become an obligation, stemming from the European Legislations (91/676/EEC Nitrates Directive [38]; WFD 2000/60/EC [19]; 2006/118/EC Groundwater Directive [39]; 2007/60/EC Directive on the Assessment and Management of Flood Risks [40]) and the associated national legislations. The latest updates in the WFD revision process indicate 2021 and 2027 as the next target years for achieving good ecological status in all European waters [41]. For supporting this aim, real-time monitoring infrastructure for water should cover at least geographical areas of high and medium priority in accordance with existing waterbodies of less than good ecological status, so as to enhance the capacity of competent authorities to undertake timely relevant mitigation and protection measures for those waterbodies. Such aims are feasible today because of the technological progress in water monitoring with the production of new generation sensors and telecommunication protocols, and lower operational and maintenance costs, which allow the establishment of permanent, large-scale monitoring networks $[42,43]$.

\subsection{GIS-Based Multicriteria Decision Analysis}

The design of the national network for automatic monitoring of water quality parameters was performed with a GIS-based multicriteria decision analysis (GIS-MCDA) approach. GIS-MCDA is a process for spatial decision-making that combines and transforms spatial data into a resultant output [44]. Here, the conventional GIS-MCDA - a multiattribute decision analysis (MADA) approach that involves a predetermined, limited number of alternatives (options from which we can choose from) and assumes spatial homogeneity of preferences (desired performance outcomes in the future) with respect to different levels of criterion (attributes and objectives) values—was adopted [45,46]. GIS-MCDA involves three main concepts: value scaling (or standardization), criterion weighting, and combination (decision) rule [47].

Value scaling or standardization is the procedures for transforming raw data to comparable units [45]. The most common GIS-based method for standardizing evaluation criteria is the score range procedure, which is a special case of the value/utility function method for value scaling [47]. Criterion weighting is the procedure of value assigning to an evaluation criterion, which indicates its importance relative to the other criteria under consideration [45]. Criterion weighting methods can be classified into two groups: the global methods (ranking, rating, pairwise comparison, and entropy approaches) that are based on the assumption of spatial homogeneity of preferences, and spatially explicit criterion weighting methods (proximity-adjusted criterion weights, range-based local weighting, and entropy-based local weighting methods) that take into account spatial heterogeneity 
of preferences [45]. Finally, combination (decision) rule is a procedure or method for evaluating (and ordering) a set of decision alternatives (criterion maps) and decision-maker's preferences (criterion weights) into an overall assessment of the alternatives [45].

A number of multicriteria methods have been implemented in the GIS environment including weighted linear combination (WLC), reference point methods, and outranking analysis [48]. In the specific effort, the weighted linear combination (WLC) model, the most straightforward and one of the most commonly GIS-MCDA models used [48,49], was employed. In WLC the decision rule evaluates each alternative with the following value function, $S$.

$$
S=\sum_{j} w_{j} v_{j}\left(x_{i}\right)=\sum_{j} w_{j} r_{i j}
$$

where $w_{j}$ is a normalized weight $\left(\sum w_{j}=1\right) ; v_{j}\left(x_{i}\right)$ is the value function for the $\mathrm{j}$-th attribute; $x_{i}=x_{i 1}$, $x_{x 2}, \ldots, x_{i n}$; and $r_{i j}$ is the attribute transformed into the comparable scale [44,49].

Factor standardization can be achieved based on the assumption that the value function has a linear shape:

$$
x_{i}=\frac{\left(R_{i}-R_{\min }\right)}{\left(R_{\max }-R_{\min }\right)} \times S R
$$

where $R_{i}$ is the raw score $i, R_{\min }$ is the minimum score of each factor, $R_{\max }$ the maximum score of each factor, and $S R$ is the standardized range [44,50]. If all criteria examined are qualitative, the score ranking can be attributed subjectively, ranging between 1 (small disturbance) and 5 (high disturbance).

Criterion weighting was based on the pairwise comparisons method in the context of a decision-making process known as the Analytic Hierarchy Process (AHP) [51] and relies on the judgements of experts to derive priority scales. This method has been tested for a variety of decision situations (site selection problems, land suitability analysis, and environmental impact assessment [45]). AHP provides a formal structure to problems, simplicity, consistency, and versatility. Nevertheless, the pairwise comparison method can be criticized regarding the ambiguity of the underlining questions [52]. In the specific effort three environmental scientists of Hellenic Centre for Marine Research specialized in water resources management involved in the procedure. The priority scales were derived after synthesizing their judgements using geometric mean of the final outcomes, as proposed by Saaty [53]. AHP employs a fundamental scale of values to represent the intensities of judgments, ranging between 1 and 9 (Table 1) [54]. All identified criteria are compared against each other in a pairwise comparison matrix. Once the pairwise comparison matrix is obtained, a vector of criterion weights, $w=\left(w_{1}, w_{2}, \ldots, w_{n}\right)$ can be computed. The weights are obtained as the unique solution to

$$
C_{w}=\lambda_{\max } w,
$$

where $\lambda_{\max }$ is the largest eigenvalue of $C$. The consistency ratio $C R$ of a pairwise comparison matrix defines the probability that the matrix ratings (rating of each criteria against each other regarding their relative importance) were randomly generated. $C R$ can be defined as

$$
C R=\frac{\lambda_{\max }-n}{R I(n-1)}
$$

where $n$ is the number of criteria under consideration and $R I$ is the random index, which is the consistency index of a randomly generated pairwise comparison matrix and depends on the number $n$ of elements being compared (Table 2). $C R$ ratings greater than 0.10 indicate that the pairwise judgments are almost random and untrustworthy [55] and therefor $C R$ should be re-evaluated [56], while $C R$ smaller than 0.10 indicates a reasonable level of consistency in the pairwise comparisons [54] and that the adjustment is small compared to the actual values of the eigenvector entries [54]. 
Table 1. The fundamental scale for pairwise comparison [54] (copyright permission see Supplementary Materials).

\begin{tabular}{cc}
\hline Intensity of Importance & Definition \\
\hline 1 & Equal importance \\
2 & Weak \\
3 & Moderate importance \\
4 & Moderate plus \\
5 & Strong importance \\
6 & Strong plus \\
7 & Very strong or demonstrated importance \\
8 & Very, very strong \\
9 & Extreme importance \\
\hline
\end{tabular}

Table 2. Average random consistency index (RI) [54].

\begin{tabular}{cccccccccc}
\hline $\boldsymbol{n}$ & $\mathbf{1}$ & $\mathbf{2}$ & $\mathbf{3}$ & $\mathbf{4}$ & $\mathbf{5}$ & $\mathbf{6}$ & $\mathbf{7}$ & $\mathbf{8}$ & $\mathbf{9}$ \\
\hline$R I$ & 0.00 & 0.00 & 0.52 & 0.89 & 1.11 & 1.25 & 1.35 & 1.40 & 1.45 \\
\hline
\end{tabular}

In the present effort the extension for ArcGIS 10.4 extAHP 2.0 for multicriteria analysis using analytical hierarchy process (AHP) developed by [57] was used.

\subsection{Conditioning Factors}

Activities and factors that impose a pressure on rivers or increase the need for river water quality monitoring were included in the analysis. The main factors that impose significant pressures on Greek rivers [58], and that were examined in the specific effort, were agricultural and industrial activities, the hydrogeological structure, the capacity of urban wastewater treatment plants (UWWTP), the type of hydraulic structures in rivers and the existence of area protected under legislation.

\subsubsection{Agricultural Activities}

Areas with intense agricultural activities are expected to impose significant pressure on river water quality, due to the use of fertilizers and other agrochemical inputs (e.g., pesticide, manure, and herbicides), but also due to water abstraction for irrigation [59]. The spatial distribution of agricultural activities in Greece were retrieved from CORINE Land Cover 2012 [60]. Based on CORINE 2012 inventory, the total agricultural area in Greece is $51,650 \mathrm{~km}^{2}$, the majority of which is occupied by nonirrigated land $(25 \%)$ and land principally occupied by agriculture $(24 \%)$, followed by permanently irrigated land (15\%), complex cultivation patterns (15\%), and olive groves (14\%; Figure 1a). For each agricultural activity a standardized value was attributed, based on the pressures it poses on surface water quality, depending on the general agricultural practices proposed by agricultural engineers regarding nutrient management in Greece [61]. 


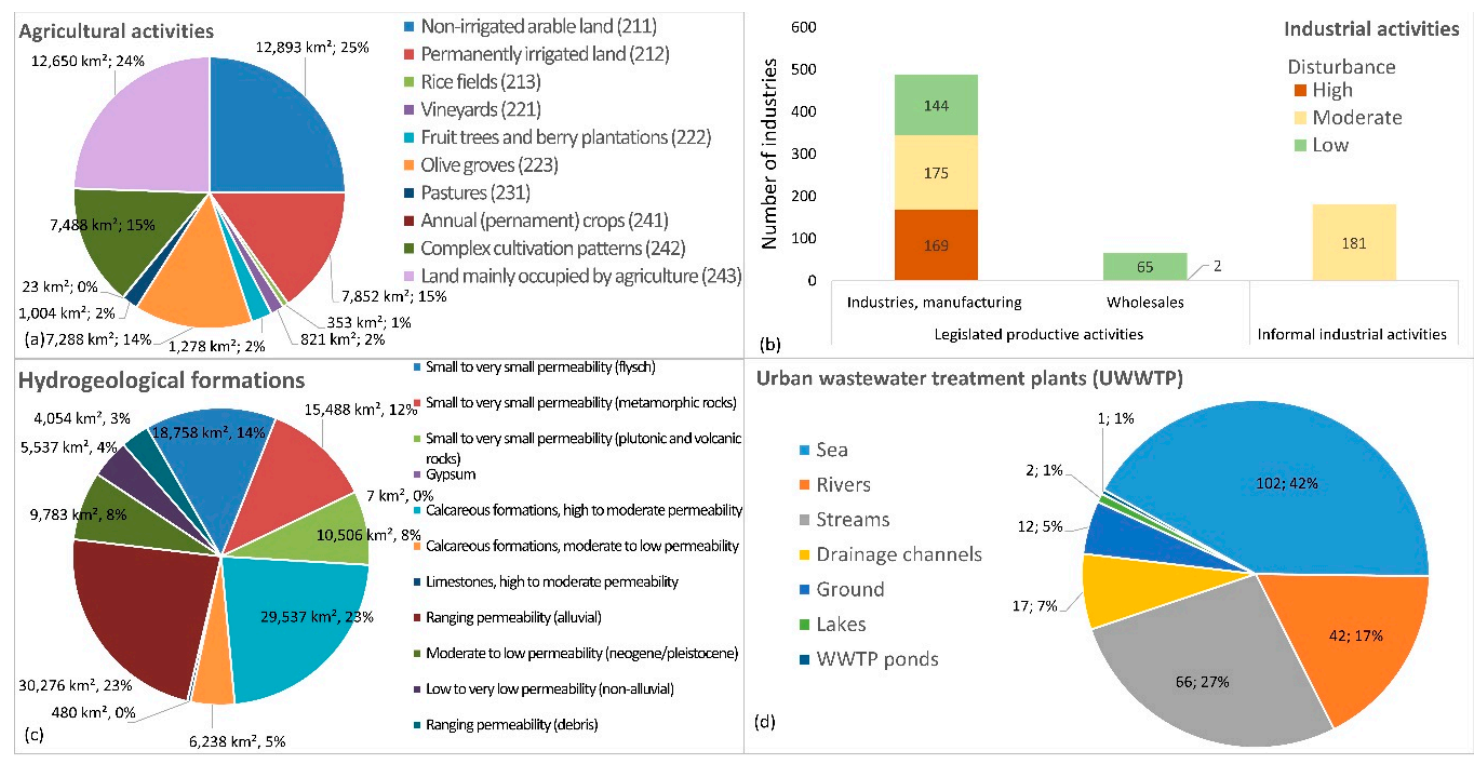

Figure 1. (a) Agricultural activities, (b) industrial activities, (c) hydrogeological structure, and (d) urban wastewater treatment plants of Greece.

\subsubsection{Industrial Activities}

In the present effort, in order to identify the pressures on river's water quality due to industrial and other related activities, the database of the General Secretariat for Industry (GSI) under the Hellenic Ministry of Economy \& Development was used [62]. Based on this inventory, the number of legislated productive activities (industries, manufacturing, and wholesales) of Greece were 555, while the informal industrial activities were 181 (Figure 1b). The classification of the areas, where industrial activities occur, was based on the expected disturbances on the surrounding environment. These areas where classified in three categories (low, moderate, and high disturbance), depending on the detailed description of each activity in the inventory. The impact of informal industrial activities was characterized as "moderate", since the information in these cases were limited. Finally, a normalized value was attributed to the disturbances classes, depending on the impact on river's water quality that lead to an increased need for monitoring.

\subsubsection{Hydrogeological Structure}

The hydrogeological structure of an area is an important factor affecting the water quality of the groundwater and eventually surface water, since they interact in a complex and direct or indirect manner [63]. Groundwater can be protected to a large extent from contamination by the natural purifying action of the soil and other geological formations through which water must infiltrate to reach underground aquifers [3]. Sand, silt, and clay of soils or of the layers inside the underlying geological formations slowly infiltrate bacteria and other small particles from water, chemical substances are adsorbed by small particles, bacteria degrade agricultural and industrial chemicals, while dissolved organic material in the soil decompose bacteria [3]. On the other hand, karstic formations are very vulnerable to pollution, due to small thickness of the protective soil coverage, the small infiltration of water through the karstic network and the rapid movement of the groundwater that does allow the decay of pathogenic organisms [64]. In Greece, karst aquifers are characterized by high to very high vulnerability as well as pollution risk [65]. Based on the hydrogeological map of Greece [66], 28\% of the total area is covered by carbonate formation and $38 \%$ by porous formations (Figure 1c). The classification of the geological formations was based on their vulnerability to pollution, with calcareous formations being the most vulnerable and impervious the least. Finally, a normalized value was attributed to the hydrogeological formations, depending on the pollution risk they impose on river's water quality. 


\subsubsection{Urban Wastewater Treatment Plants (UWWTP)}

The effluents from wastewater treatment plants disposed to surface waters can in some cases impose an additional pressure on rivers. The quality of treated wastewater disposed depends on the composition of the initial, untreated wastewater, and whether all the stages of the treatment (preliminary, primary, secondary, and tertiary/advanced; nitrogen/phosphorus removal; and disinfection) have been completed successfully [67]. The data concerning the urban wastewater treatment plants (UWWTP) were retrieved from the National Database of the Urban Waste Water Treatment Plants (UWWTPs) designed and developed by the Special Secretariat for Water of Ministry of Environment and Energy, in the framework of the requirements of the Directive 91/271/EEC [68,69]. Within the database technical and operational data of the UWWTPs in Greece, information on the means of disposal or reuse of waste water and sludge, as well as the environmental terms of each UWWTP are stored and are publicly available [69]. Based on the database, 242 UWWTPs operate in Greece (April 2018), 102 of which dispose treated wastewater directly to the sea, 125 to rivers, streams, or irrigation/drainage channels and 15 to the ground, lakes, or wastewater treatment ponds (Figure 1d). The classification and the standardized value attributed to the UWWTPs that dispose treated wastewater directly rivers, streams, or irrigation/drainage channels were based on their physical capacity (population equivalent).

\subsubsection{Protected Areas}

Areas included in environmental protection networks, such as NATURA 2000, CORINE biotopes, wildlife refuges, etc., require monitoring and assessment of their ecological condition so as to identify possible management actions to be undertaken [70]. In Greece areas in environmental protection networks are protected under national legislation or after ratification of international or European conventions. In some cases areas from different environmental protection networks overlap. In the present effort the European inventory of nationally designated areas that holds information about protected areas was used [71]. The total area of sites of environmental interest under protection is $68,990 \mathrm{~km}^{2}$ (Table 3; Figure 2a). A uniform value regarding the increased need for monitoring was attributed to all protected areas of Greece. 
Table 3. Environmental protection networks in Greece.

\begin{tabular}{|c|c|c|c|c|}
\hline Type & Legislation & OJHR & No & Area $\left(\mathrm{km}^{2}\right)$ \\
\hline \multicolumn{5}{|c|}{ National Networks } \\
\hline National Woodland Park & LD 86/1969; LD 996/1971 & 7A/1969; 162A/1971 & 10 & 767 \\
\hline National Park & L 1650/1986 & 160A/1986 & 17 & 9645 \\
\hline Aesthetic Forest & LD 86/1969; LD 996/1971 & 7A/1969; 162A/1971 & 19 & 319 \\
\hline Wildlife Refugee & L 177/1975; L 2637/1998 & $\begin{array}{l}\text { 205A/1975; } \\
\text { 200A/1998 }\end{array}$ & 603 & 10,632 \\
\hline Controlled Hunting Area & L 177/1975; L 2637/1998 & $\begin{array}{l}\text { 205A/1975; } \\
\text { 200A/1998 }\end{array}$ & 7 & 1115 \\
\hline Game Breeding Station & L 177/1975; L 2637/1998 & $\begin{array}{l}\text { 205A/1975; } \\
\text { 200A/1998 }\end{array}$ & 21 & 31 \\
\hline $\begin{array}{l}\text { Natural Monuments and landmarks } \\
\text { (protected as strict nature reserve) }\end{array}$ & LD 86/1969; LD 996/1971 & 7A/1969; 162A/1971 & 9 & 160 \\
\hline Protected Forests & - & $65 \mathrm{D} / 2006$ & 3 & 418 \\
\hline Nature Reserve Area & L 1650/1986 & $160 \mathrm{~A} / 1986$ & 38 & 2678 \\
\hline Absolute Nature Reserve Area & L $1650 / 1986$ & $160 \mathrm{~A} / 1986$ & 11 & 118 \\
\hline $\begin{array}{l}\text { Protected significant natural } \\
\text { formations and landscapes }\end{array}$ & L 1650/1986 & 160A/1986 & 3 & 37 \\
\hline Other & - & - & 41 & 6529 \\
\hline \multicolumn{5}{|c|}{ European Networks } \\
\hline NATURA 2000 & - & 4432B/2017 & 446 & 58,773 \\
\hline $\begin{array}{c}\text { Biogenetic Reserves (Council of } \\
\text { Europe) }\end{array}$ & - & - & 16 & 254 \\
\hline $\begin{array}{c}\text { European diploma (Council of } \\
\text { Europe) }\end{array}$ & - & - & 1 & 48 \\
\hline \multicolumn{5}{|c|}{ International Networks } \\
\hline $\begin{array}{c}\text { Ramsar Convention (Convention on } \\
\text { Wetlands) }\end{array}$ & $\begin{array}{c}\text { LD 191/1974; L 1751/1988; L } \\
\text { 1950/1991 }\end{array}$ & $\begin{array}{c}350 \mathrm{~A} / 1974 ; \\
26 \mathrm{~A} / 1988 ; 84 \mathrm{~A} / 1991\end{array}$ & 10 & 1635 \\
\hline UNESCO-World Heritage List & L 1126/1981 & 32A/1981 & 18 & 396 \\
\hline UNESCO-Biosphere reserves & - & - & 2 & 94 \\
\hline Barcelona Convention & L 855/1978; L 1634/1986 & $\begin{array}{l}\text { 235A/1978; } \\
104 \mathrm{~A} / 1986\end{array}$ & 9 & 2578 \\
\hline
\end{tabular}

LD: Legislative Decree; L: Law; OJHR: Official Journal of the Hellenic Republic.
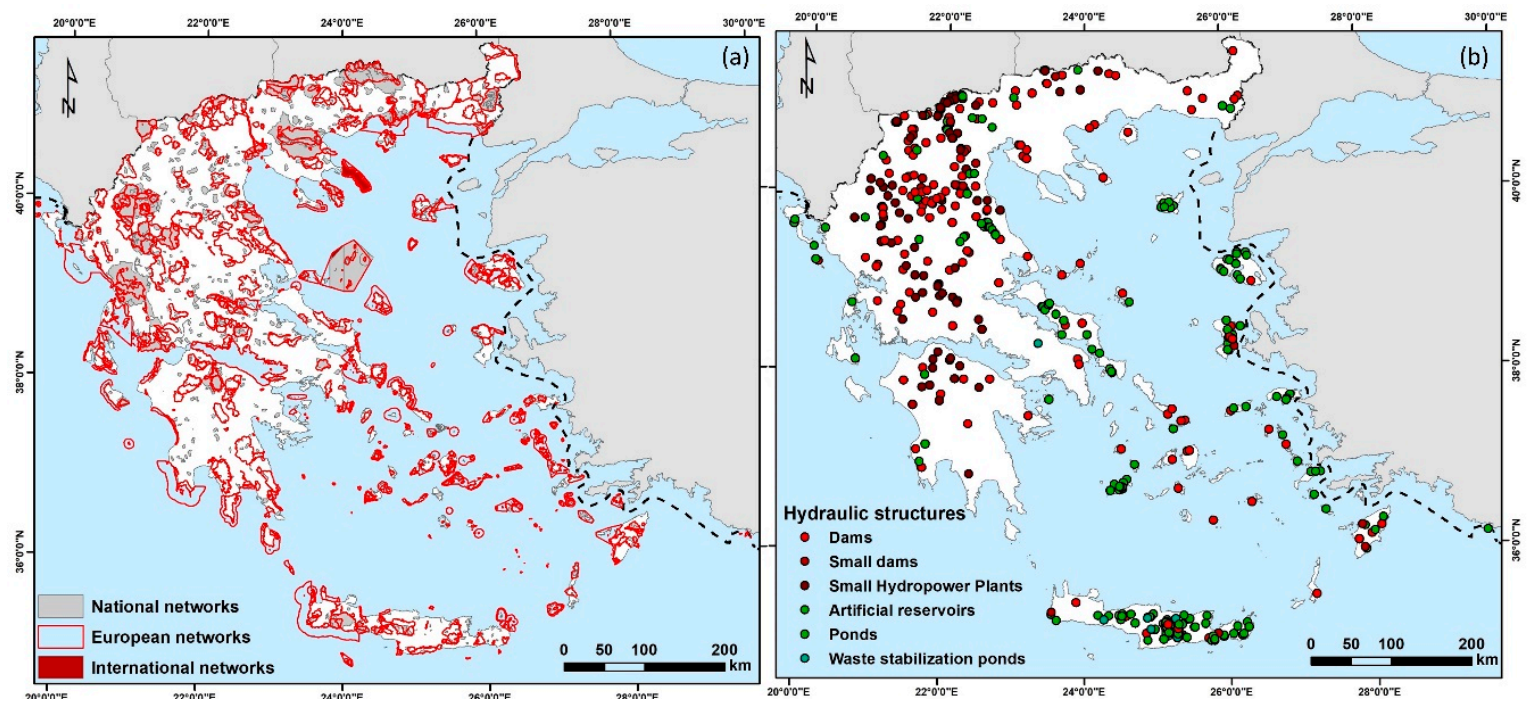

Figure 2. (a) Protected areas and (b) hydraulic structures in rivers, of Greece.

\subsubsection{Hydraulic Structures in Rivers}

Hydraulic structures, such as dams, weirs, spillways, cut slopes, and sluices, impose significant pressures to rivers flow, but also water quality. Flow alteration due to hydraulic structures can lead to changes in river water temperature (e.g., it was found that the occurrence of high water temperatures can be attributed to low river flow rate downstream two dams [72]). Avilés and Niell [73] found an important spatial heterogeneity in the nutrient content and water properties of lowland catchment due 
to the effects of the small dam. In other cases, the longer retention of the water in the artificial lake upstream a dam can lead to a greater accumulation of allochthonous organic matter, with consequences on the availability of this material below the reservoir [74]. Additionally, flow regulation can intensify the capacity of downstream river reaches to store and process materials and energy, therefore increasing the amount of organic carbon processed and altering the whole flux of materials and energy along the river continuum [75]. Finally, river control structures such as levees or dikes deprive floodplains from receiving periodic renourishment and sediment fluxes [76].

The main hydraulic structures of interest in the specific effort are large and small dams, small hydropower plants (SHPs), small reservoirs, ponds, and waste stabilization ponds. Based on the International Commission On Large Dams (ICOLD), a dam is defined as large when the height between the lowest foundation and the crest is greater than $15 \mathrm{~m}$, or when the height is between 5 and $15 \mathrm{~m}$ and the impounding is more than $3 \times 10^{6} \mathrm{~m}^{3}$ [77]. SHPs are defined as the hydropower plants with maximum install capacity $15 \mathrm{MWp}$ (Law 3468/2006 [78]). A pond is a natural or artificial body of standing water between $1 \mathrm{~m}^{2}$ and 2 ha in area [79], which usually holds water for at least 4 months of the year [80]. Artificial reservoirs, which are commonly constructed in Greece, are man-made, off-stream ponds created in an area where topographic features favor the deposit of water from streams' or small rivers' diversion, and are usually waterproofed with geomembranes or compacted/geosynthetic clay liners [81]. The difference between artificial ponds and reservoirs is not always distinct. Here only artificial ponds without waterproofing, artificial reservoirs, and waste stabilization ponds that constitute a special case of artificial ponds, were included in the analysis.

For the present effort the registry of Greek Large Dams in operation conducted by Greek Committee on Large Dams [82] was used, after validation and update, while also the large dams under construction were included. Additionally, the registry of small dams and artificial reservoirs [81] and the on-line registry of Land Reclamation Projects of Ministry of Rural Development and Food of Greece [83] were used. The data concerning the SHPs with operational license were retrieved from Regulatory Authority for Energy of Greece [84].

Based on the inventory, 166 large dams, 23 small dams, 94 SHPs, and 233 artificial ponds, reservoirs and waste stabilization ponds are constructed or are under construction in Greece until 2018 (Figure 2b). Dams and SHPs are mainly located in the continental Greece, while artificial ponds and reservoirs are located mainly in islands. It should be noted that in Greece only few dams can be defined as small [77]. This is because although the capacity of the majority of the dams that have been classified as large is small, despite being high, due to the morphology of the construction area. It should also be noted that the inventory of hydraulic structures in rivers of Greece is constantly being updated.

The classification and the standardized value attributed to the hydraulic structures in rivers was based on the pressures they pose on surface water quality, with large dams imposing the greatest pressure and off stream reservoirs and artificial ponds posing the least.

\subsection{Designation of Areas with Increased Need for Monitoring}

All the aforementioned factors processed with the AHP methodology resulted in the production of a map where the high priority areas for water quality monitoring were highlighted. In order to identify the sub-basins with increased needs for water quality monitoring, a score Sc was attributed to each one based on the total summation $\Sigma(\mathrm{S})$ of multicriteria analysis and divided by the area $\mathrm{A}$ of the sub-basin:

$$
\mathrm{Sc}=\Sigma(\mathrm{S}) / \mathrm{A},
$$

The spatial dataset used for the analysis was the European Catchments and Rivers Network System-ECRINS [85].

The classification of the sub-basins into five classes (very high, high, moderate, low, and very low) was performed with the quantile method, which distributes a set of values into groups that contain an equal number of values and produces distinct map patterns. This method is commonly used in similar vulnerability risk assessment models based on GIS multicriteria analysis successfully 
and its superiority has been established over others (e.g., equal interval, quantile, standard deviation, and natural break $[86,87])$. The final output was a map with the sub-basins of Greek classified in five classes (very high, high, moderate, low, and very low) describing the need for rivers' water quality monitoring.

Finally, in order to investigate the reliability of the methodological approach, the output map was contrasted with the results of the National Monitoring Program 2012-2015 of the water status in Greece [88]. More specifically, for each of the 299 monitoring stations of the aforementioned project the quality status was estimated based on the Nutrient Classification System (NCS) [89] modified to also include dissolved oxygen concentrations [90] (Table 4) and after averaging each status. Then, the quality class of each station was contrasted to the class describing the need for river water quality monitoring. The criteria used to check the reliability was the correlation coefficient $R$.

Table 4. Quality status in rivers based on the Nutrient Classification System (NCS) [89] (copyright permission see Supplementary Materials) and dissolved oxygen concentrations [90].

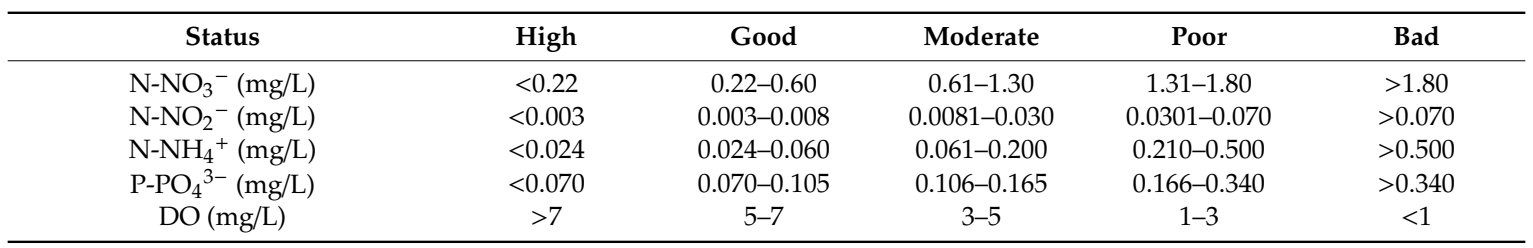

\subsection{Current Automatic Monitoring Network of Water Quality Parameters in Greece}

To identify automatic water monitoring stations in Greece, internet services were used to explore all possible sources of information. Also, direct communication with relevant authorities and organizations was held. An extended questionnaire was formulated and distributed to water agencies and water management authorities, research institutes, universities, and organizations dealing with water, including questions related to the current status of possible automatic stations installed and operated by them, along with their characteristics in terms of the equipment used, the parameters measured and time step of recording, and the duration of stations operation. From the responses received ( $25 \%$ of the stakeholders questioned), almost 150 stations were identified in waterbodies across Greece, being individual or small networks of automatic stations, either currently operating or stations that have stopped operating but were active for a considerable period of time in the past. As minimum requirement for considering a station as automatic water quality station of present or past, thus including it in our survey, was the continuous measurement and telemetric data transmission of five parameters; water stage, dissolved oxygen (DO), water temperature (T), electrical conductivity (EC), and $\mathrm{pH}$.

\section{Results}

\subsection{GIS-Based Multicriteria Decision Analysis}

The six (6) conditioning factors increasing the need for water quality monitoring of rivers have been ranked in Table 5, which produced the maps in Figure 3. The pairwise criteria comparison based on the AHP approach resulted to the preference matrix with assigned preference values and calculated weights (Table 6), and to a consistency ratio $C R$ of 0.018 . This value is smaller than 0.10 and meets the criteria set by [54]. After performing a weighted summation of the maps corresponding to each conditioning factor examined, the final map of the high priority sub-basins of Greece for water quality monitoring of rivers was produced (Figure 4). 
Table 5. Weights of the factors increasing the need for monitoring of water quality parameters of rivers in Greece.

\begin{tabular}{|c|c|c|c|}
\hline $\mathrm{a} / \mathbf{a}$ & Conditioning Factors & Class & Rank Values \\
\hline \multirow{10}{*}{1} & \multirow{10}{*}{ Agricultural } & Nonirrigated arable land (211) & 1 \\
\hline & & Permanently irrigated land (212) & 3 \\
\hline & & Rice fields (213) & 4 \\
\hline & & Vineyards (221) & 1 \\
\hline & & Fruit trees and berry plantations (222) & 1 \\
\hline & & Olive groves (223) & 1 \\
\hline & & Pastures (231) & 1 \\
\hline & & $\begin{array}{c}\text { Annual crops associated with permanent } \\
\text { crops (241) }\end{array}$ & 4 \\
\hline & & Complex cultivation patterns (242) & 2 \\
\hline & & $\begin{array}{l}\text { Land principally occupied by agriculture } \\
\qquad(243)\end{array}$ & 1 \\
\hline \multirow{4}{*}{2} & \multirow{3}{*}{ Industrial } & Low disturbance & 2 \\
\hline & & Average disturbance & 3 \\
\hline & & High disturbance & 5 \\
\hline & $\begin{array}{l}\text { Informal industrial } \\
\text { concentration }\end{array}$ & - & 3 \\
\hline \multirow{5}{*}{3} & \multirow{5}{*}{ Geological structure } & Impervious formations (A1, A2, A3) & 0 \\
\hline & & $\begin{array}{l}\text { Calcareous formations, medium to high } \\
\text { permeability }(\mathrm{K} 1, \mathrm{~K} 3, \mathrm{~g})\end{array}$ & 3 \\
\hline & & $\begin{array}{l}\text { Calcareous formations, small to medium } \\
\text { permeability (K2) }\end{array}$ & 2 \\
\hline & & $\begin{array}{l}\text { Porous formations, ranging permeability } \\
\qquad(\mathrm{P} 1, \mathrm{P} 4)\end{array}$ & 2 \\
\hline & & $\begin{array}{l}\text { Porous formations, medium to very small } \\
\text { permeability }(\mathrm{P} 2, \mathrm{P} 3)\end{array}$ & 1 \\
\hline \multirow{5}{*}{4} & Wastewater Treatment plants & $0-5000$ & 1 \\
\hline & & $5000-15,000$ & 2 \\
\hline & Physical Capacity (Population & $15,000-30,000$ & 3 \\
\hline & equivalent) & $30,000-60,000$ & 4 \\
\hline & & $>60,000$ & 5 \\
\hline 5 & Protected areas & & 1 \\
\hline \multirow{4}{*}{6} & \multirow{4}{*}{ River structures } & Dam & 5 \\
\hline & & Small dam & 3 \\
\hline & & Small Hydropower Plants (SHP) & 2 \\
\hline & & Reservoirs, artificial ponds & 1 \\
\hline
\end{tabular}




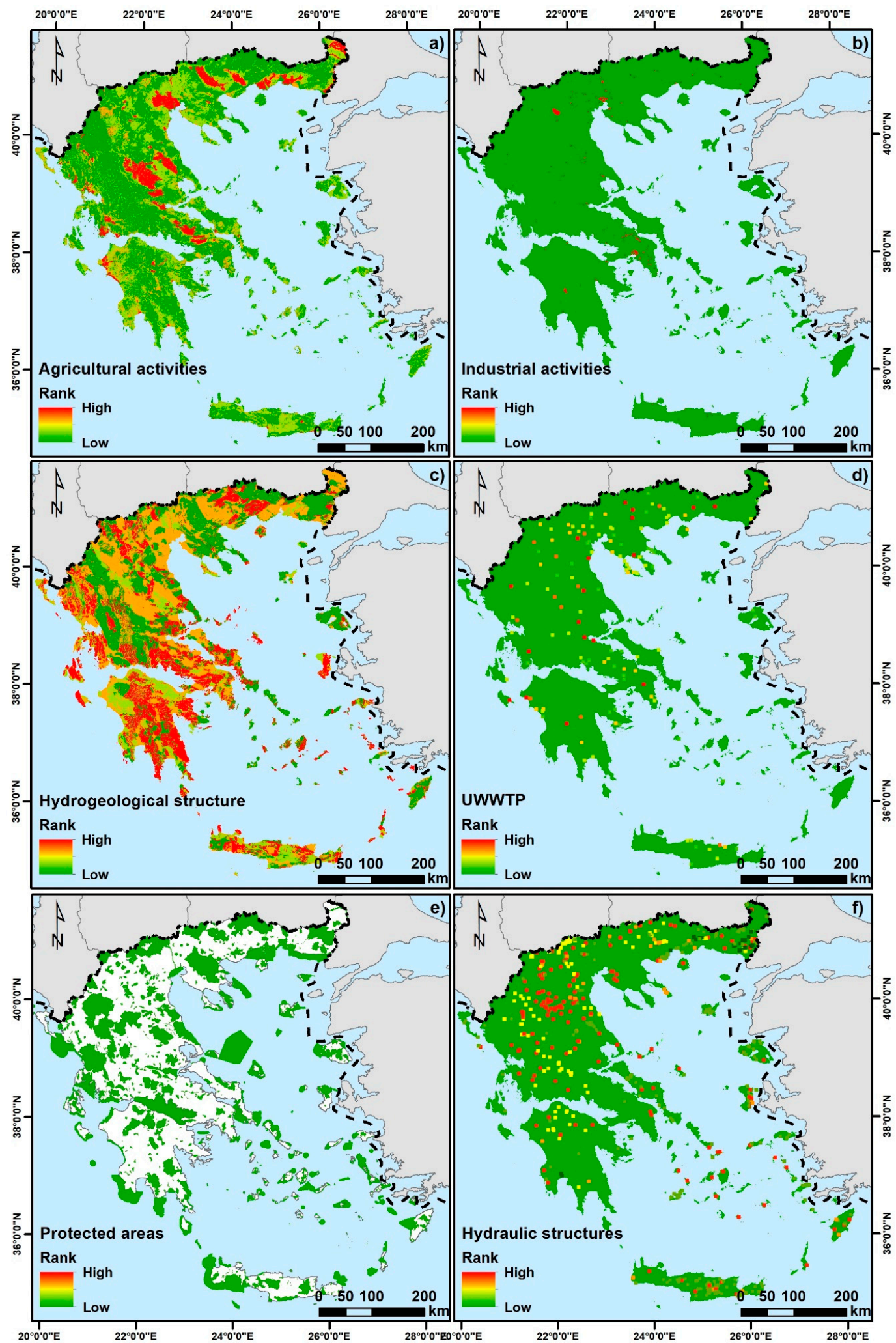

Figure 3. Conditioning factors increasing the need for water quality monitoring. (a) Agricultural activities, (b) industrial activities, (c) Hydrogeological structure, (d) UWWTP, (e) protected areas, and (f) hydraulic structures in rivers. 
Table 6. Preference matrix with assigned preference values and calculated weights.

\begin{tabular}{|c|c|c|c|c|c|c|c|}
\hline & $\begin{array}{l}\text { Industrial } \\
\text { Activities }\end{array}$ & $\begin{array}{c}\text { Agricultural } \\
\text { Activities }\end{array}$ & $\begin{array}{l}\text { Hydraulic } \\
\text { Structures }\end{array}$ & UWWTP & $\begin{array}{c}\text { Protected } \\
\text { Areas }\end{array}$ & $\begin{array}{l}\text { Hydrogeological } \\
\text { Structure }\end{array}$ & Weight \\
\hline Industrial activities & 1 & 2 & 4 & 6 & 7 & 7 & 44.3 \\
\hline Agricultural activities & 0.5 & 1 & 2 & 3 & 4 & 5 & 23.2 \\
\hline UWWTP & 0.167 & 0.333 & 0.5 & 1 & 2 & 3 & 8.8 \\
\hline Protected areas & 0.143 & 0.25 & 0.333 & 0.5 & 1 & 2 & 5.7 \\
\hline $\begin{array}{l}\text { Hydrogeological } \\
\text { structure }\end{array}$ & 0.125 & 0.2 & 0.25 & 0.333 & 0.5 & 1 & 3.8 \\
\hline Consistency ratio $C R$ & & & & & & & 0.018 \\
\hline
\end{tabular}

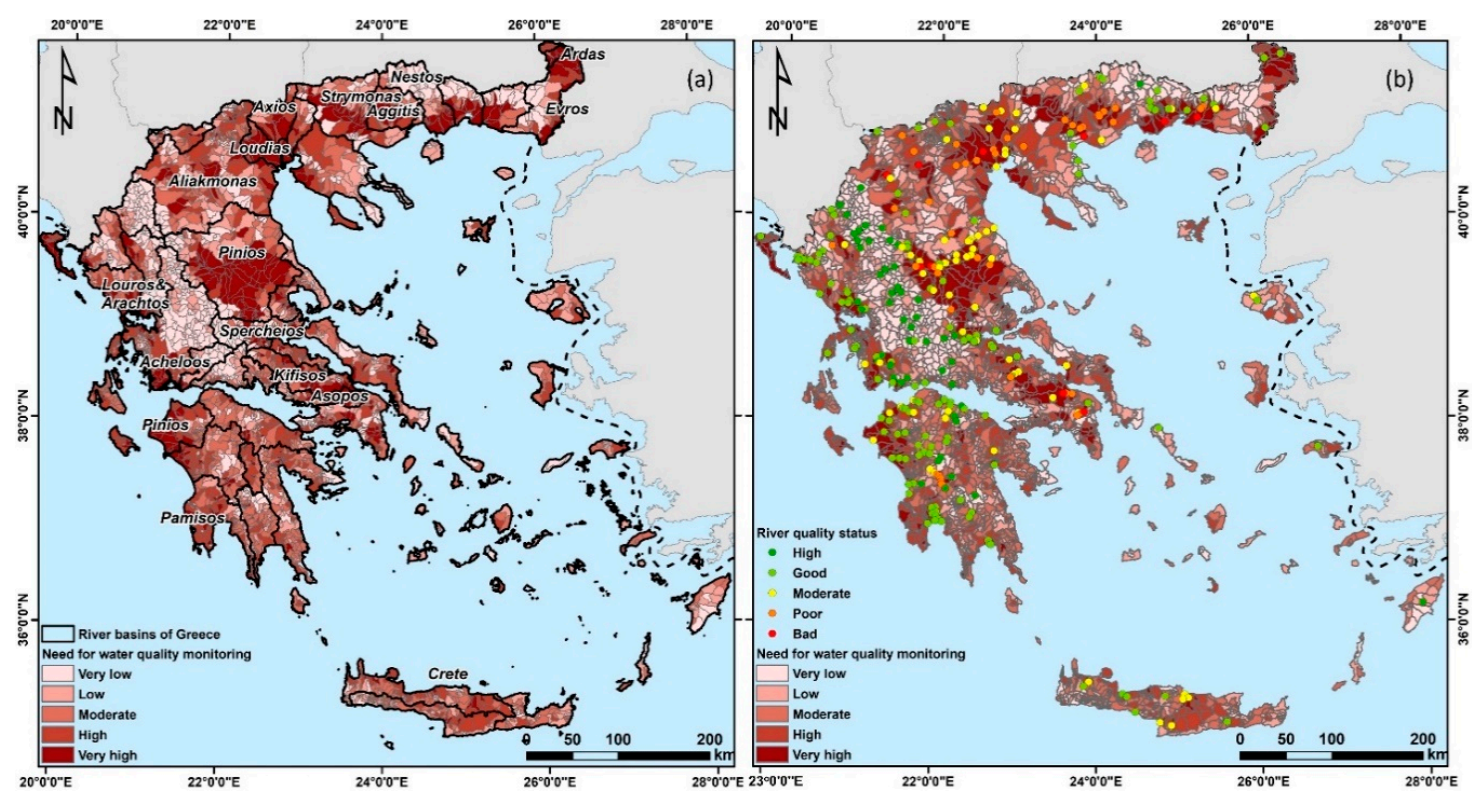

Figure 4. (a) Basins of Greece with increased need for water quality monitoring and (b) results of the national monitoring program of the water status in Greece (quality status 2012-2015).

Based on the results, the rivers with increased need for water quality monitoring are in the wider area of Thessaloniki, and especially at the estuaries of Aliakmonas, Loudias, and Axios rivers, due to increased agricultural and industrial activities observed in the particular basins. Additionally, water quality monitoring is highly necessary in Ardas River; at the estuaries of Evros and Nestos rivers; at Aggitis River; at the central part of Strymonas River; at Pinios River in Thessaly, especially at the southern part; at the central and eastern part of Spercheios River; at the central part of Kifissos River in Viotia; at the western part of Asopos River; at the estuaries of Louros, Arachtos, and Acheloos rivers; at the estuaries of Pamisos River; at the eastern part of Pinios River in Peloponnese; and at the southern-west and central part of Crete Island.

Regarding the reliability of the methodological approach, the correlation coefficient between the water quality status of samples along Greek rivers and the class of sub-basin describing the need for water quality monitoring resulted from the GIS-MCDA, was relatively high $(R=0.59$, $p$-value $<0.00001$, statistically significant at 0.05 level; Figure $4 \mathrm{~b}$ ). Some discrepancies are expected, since in many cases there is an increased need for monitoring due to higher vulnerability (e.g., in areas structured by calcareous formations) or increased interest (e.g., in areas included in environmental protection networks) that does not necessary imply poor or bad water quality status and water resources degradation. This is evident in the case of western Greece, where many areas are included in the Natura 2000 network, and in Southern Peloponnese, which is mainly structured by karstic formations that increase the need for water quality monitoring while the water quality status was high to very high. Finally, in some cases pollution pressures that lead to poor or bad water quality were not able to be included to the analysis due to lack of information. More specifically, a limitation arises 
due to pollution pressures applied on rivers' water quality that cannot be formally acknowledged (e.g., illegal waste disposal, areas lacking sewerage system, or UWWTP; unsuccessful collection and treatment of urban wastewater; misuse of fertilizers; and illegal water abstraction [91]) and included in the analysis. This is the reason why there is an inconsistency is some cases between the water quality status in Greek rivers' sampling points and the respective subcatchment class of monitoring need resulted from the GIS-MCDA (Figure 5). Nevertheless, in areas with moderate to bad water quality, the classification of monitoring needs fluctuates from moderate to very high with very limited exceptions (Figure 4b) which also validates the output of the approach. The eastern part of the country indicates higher needs for water quality monitoring while the mountainous areas that are usually pristine are classified as of very low and low monitoring importance.

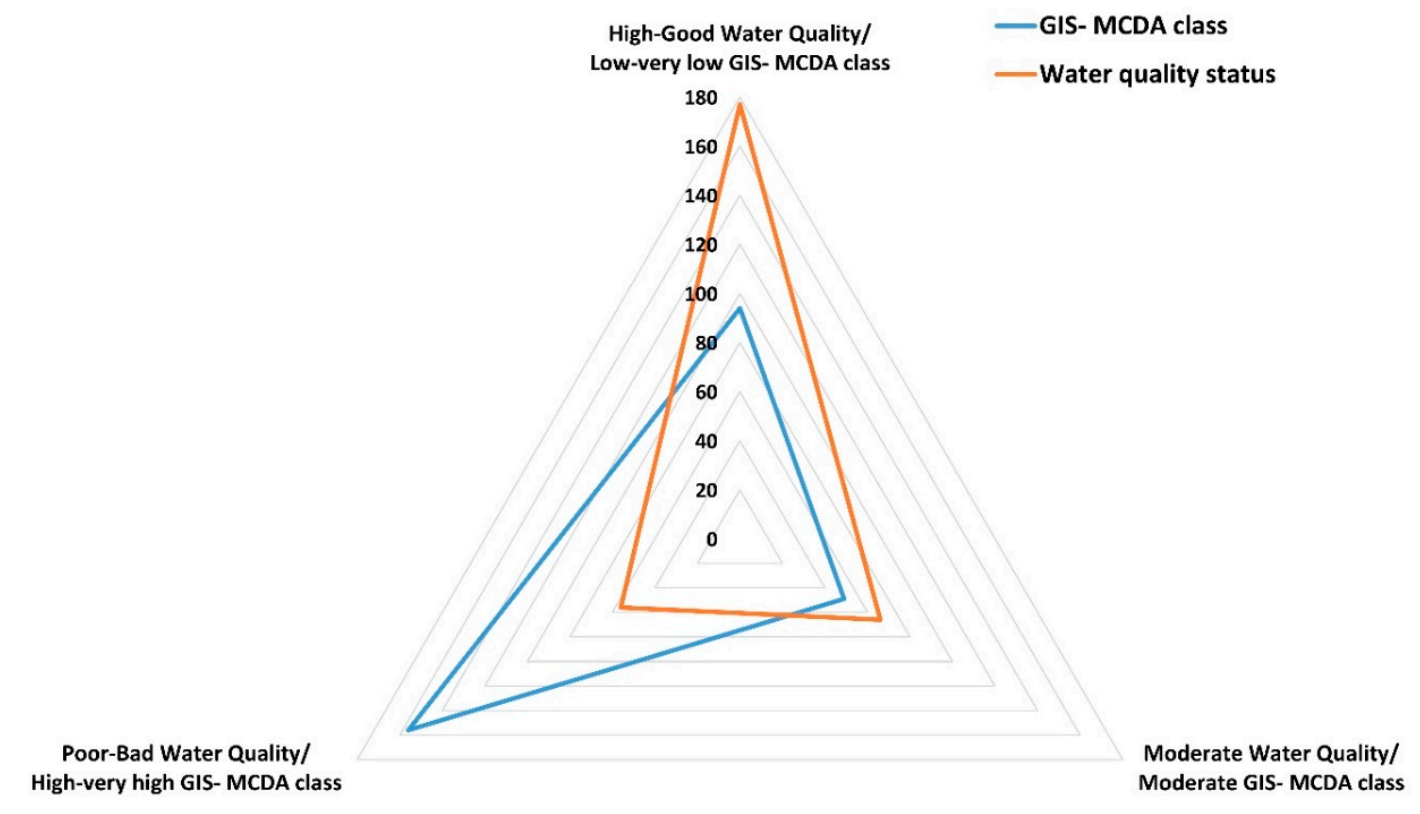

Figure 5. Comparison between water quality status in Greek rivers' sampling points and need for monitoring as resulted from GIS-MCDA.

\subsection{Current Automatic Monitoring Network of Water Quality Parameters in Greece}

Regarding the current automatic monitoring network, 145 stations were identified in the country through the analysis of the questionnaires received by various stakeholders (Figure 6). The 145 stations are depicted as circles, triangles, or rectangles if they are located in rivers (91), lakes and lagoons (32), or artificial lakes and reservoirs (22), respectively. There are 68 fully operational stations (blue), 51 stations operating partly (green), but which have the potential to fully operate after some low-cost repair, while those stations that were operational for a long period in the past but have been abandoned, stolen, or simply removed from their owners (red) are 26 in number. In practice, new equipment and full installation are needed to operate automatic stations again in these locations. The second category of stations (green) seems favorable for an immediate expansion of the operational network in Greece, as only low maintenance, usually replacement of parts of the equipment (few sensors) is required, while the infrastructure to install the station is entirely available in situ and in good condition. Most of the existing automatic stations are in northern Greece and in Crete Island while Peloponnese, western Greece and the rest of the islands have very limited number of stations. A high concentration of operational or partly operational stations is observed in the basins of Evros, Nestos, and Aliakmonas, while almost none exists in the plain of Thessaly (Pinios River), which is one of the most important agricultural areas in Greece. Moreover, in the lower parts of Acheloos river basin (Western Greece) as well as in the main western Peloponnese rivers (Alfeios and Pineios) no stations exist. 


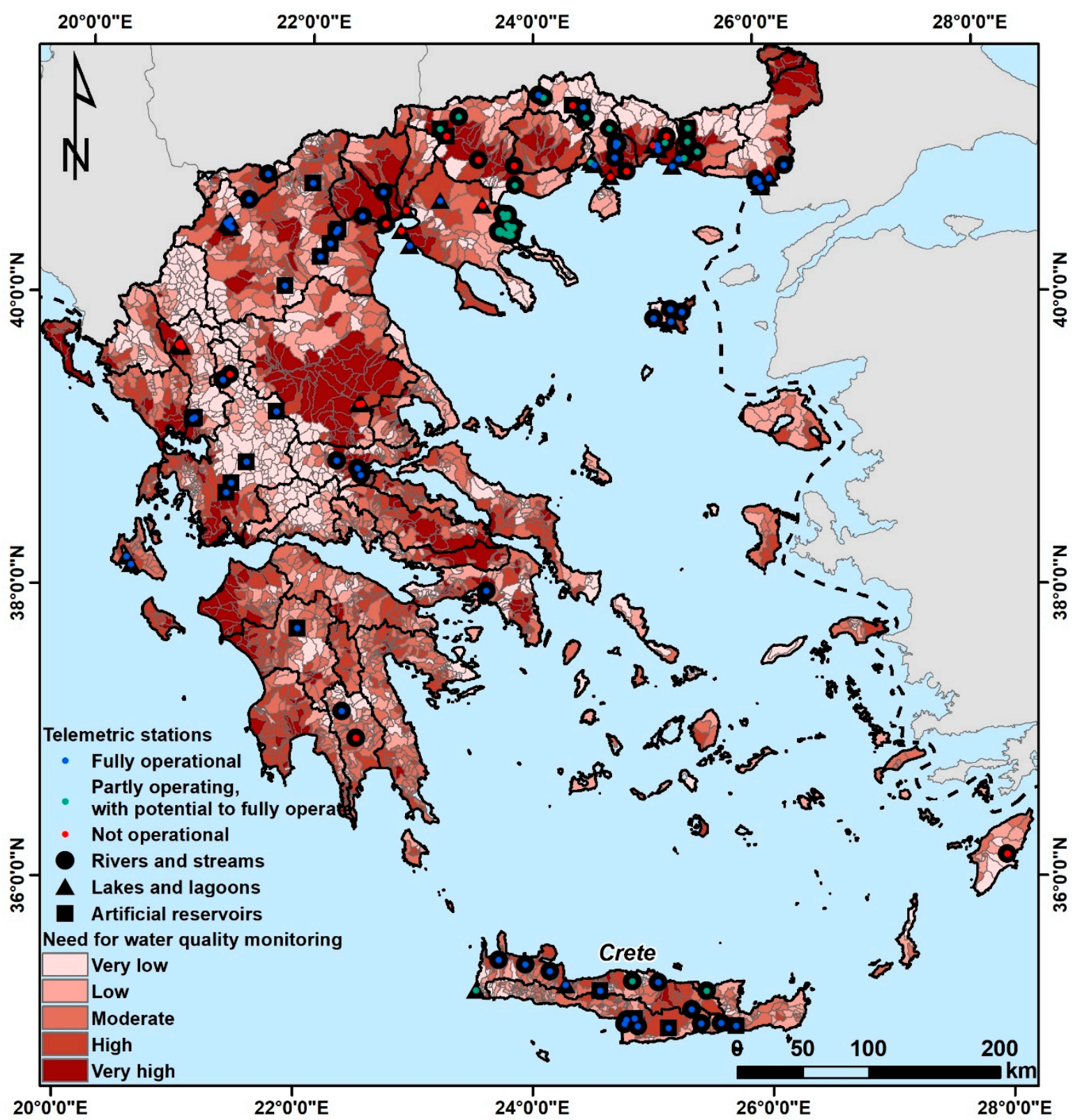

Figure 6. Water quality monitoring stations of surface waters which operate or operated in Greece along with the monitoring needs across the country expressed with colored differentiation.

\section{Discussion}

The design of a successful environmental water quality monitoring program has always been a challenge [14], and although it has been widely addressed in the published literature, there is still no generally accepted, holistic, and practical approach to support all the phases and elements related [35]. Most of the methodologies propose the selection of the water quality monitoring sites based on statistical approaches, such as principal component analysis, principal factor analysis, canonical correlation analysis, correlation analysis, cluster analysis, regression analysis, artificial neural networks, maintenance of variance extension, and matter element analysis (e.g., [30-33,92-94]). Other researchers employ other approaches and techniques, such as multicriteria decision-making analysis, genetic algorithm, entropy-based and fuzzy logic approaches, or combinations of the above (e.g., $[27-29,34,95,96])$.

Of the methodologies described above, GIS-MCDA is a cost-effective and easily applied approach that does not require qualified personnel and access to extended information, while it has been used 
successfully in the design of the networks for monitoring of water quality parameters in the past (e.g., $[27,28,95,97])$. In the present effort, the GIS-MCDA introduced takes into consideration the most important nonpoint and point pressures due to human activities, and other criteria, such as increased vulnerability, while it has been focused on Greece's particularities (e.g., the general agricultural practices taken place, the existence of informal industrial activities, the vulnerability arisen due to karstic geological formations, and the increased interest for monitoring in areas included in networks of environmental interest).

Based on the map of the existing automatic stations, Figure 6 reveals that partly operational stations (green shapes) exist entirely in northern Greece, mainly at the transboundary of the Nestos River and the Eastern Chalkidiki, where they belong to the private company "Ellinikos Chrisos", a mining company that was requested to monitor water quality of small streams in the vicinity of its installations. However, the operation of the 33 stations installed in the area was important for monitoring the environmental operation of the company but not for managing water resources at a national level. Nevertheless, the company due to legal and operational reasons stopped the monitoring system in 2017. Automatic stations installed and operated in the past but without possibility to restart their operation were found both in the North (Nestos, Strimonas, and Loudias rivers), and the central and western Greece (Acheloos River, Lake Karla, and Lake Pamvotida). Overall, the review of automatic stations in Greece has shown a very good spatial allocation in the island of Crete, as well as, in the longest river of Greece, Aliakmonas (including Lake Kastoria close to its headwaters), the estuary of the Evros River, the Nestos River and its associated lagoon, as well as the Spercheios River in Central Greece.

On the other hand, a large part of continental Greece where the largest and highly pressured river systems exist [98] remains without modern monitoring coverage. For example (Figure 5), monitoring is absent in the Epirus water district, in the northwestern part of the country, which includes the important rivers of Kalamas, Louros, and Arachtos Basins in Peloponnese with the important Pinios, Alfeios and Pamisos Rivers, as well as, in central Greece, both along the hydrologically richest Greek river, Acheloos, and within the Thessaly plain (Pinios river), the most important agricultural producer of Greece with high irrigation demands and relevant pollution pressures to waters [99]. Finally, deficiencies are still observed in the north, along the entire Greek part of the transboundary rivers Strymonas and Axios as well as in the smaller Loudias river.

Based on the above, arising from the availability of operational stations and the magnitude of the monitoring needs (Figure 5), 22 river sites in high priority areas are proposed for the immediate installation of automatic monitoring stations. The sites selected were grouped into five areas of nearby water districts and river basins that could facilitate in situ visits of the technical personnel for the installation and maintenance of the monitoring stations:

- Eight (8) stations in rivers of Peloponnese (near the estuaries and/or upstream locations of the rivers Pinios, Alfeios, Neda, and Pamisos).

- Two (2) stations at the estuaries of Kifisos and Asopos rivers in Central Greece near the Attica Region and four (4) stations in Pinios River, Thessaly Central Greece (near the estuaries and upstream sites).

- One (1) station in Acheloos river (estuaries).

- Three (3) stations in Epirus (two in Kalamas River and one in Louros).

- Four (4) stations at selected sites of the rivers Strymonas, Gallikos, Axios, and Loudias in northern Greece (one station per river).

A full cost estimation was also carried out including both the purchase and the annual maintenance costs of the stations for measuring the main parameters of interest: stage of water, $\mathrm{pH}, \mathrm{T}, \mathrm{DO}$, and EC. For the estimation of the total cost, the following formulas are used.

- $\quad$ Purchase cost (including installation): $€ 10,000 \times 22$ stations $=€ 220,000$.

- Annual personnel cost: four persons (full time job) $\times € 25,000 /$ person $=€ 100,000$. 
- Annual maintenance cost: six field workdays $\times 5$ regions to visit $\times 2$ persons $\times € 200$ daily costs (accommodation, transportation, per diem) +22 stations $\times € 1000$ consumables $=€ 34,000$.

- Therefore, for acquiring and installing 22 automatic water monitoring telemetric stations, $€ 220,000$ is required the first year and $€ 134,000$ each next year, plus the possible costs to cover any damage after the first year.

\section{Conclusions}

- The GIS-based multicriteria decision analysis methodological approach adopted in this study proved to be efficient in identifying the priority areas regarding the water quality monitoring needs in Greece, since the areas classified as of moderate to bad water quality, according to the official WFD monitoring program, have been also characterized as of moderate to very high monitoring necessity. Moreover, the correlation coefficient between water quality and monitoring necessity indices was quite high at the country level, while the known areas of high pollution pressures (industrial or agricultural activities) were in most cases classified also as of high monitoring need. At the same time, the developed methodology has some limitations. The main weakness lies in the inability to include the informal point and nonpoint pollution sources and pressures, such as illegal disposal of untreated sewage and industrial wastes, areas lacking sewerage system or UWWTP, malfunction of UWWTP, misuse of fertilizers, and illegal water abstraction. Continuous updates and integration of the current databases of the conditioning factors used in the analysis will improve the performance of the adopted GIS-based multicriteria decision analysis methodological approach in the future.

- Greece is mostly an agricultural and touristic country, while almost $35 \%\left(46,201 \mathrm{~km}^{2}\right.$ of dryland) of the total area of the country is included in networks of environmental interest. Therefore, the main farming plains as well as parts of the country's coastal or mountainous areas with high environmental interest that are vulnerable due to increased tourism or other activities, demand water quality monitoring in a regular and frequent basis. Such monitoring requirements can be satisfactorily covered by state-of-the-art, automatic, and telemetric monitoring stations that can provide nowcasting and early warning services essential for mitigating potential pollution and flood events in a timely and efficient manner. The current automatic monitoring network of water quality parameters is insufficient to meet these needs.

- Under this scope the research project "Hellenic Integrated Marine-Inland waters Observing Forecasting and offshore Technology System, HIMIOFoTS" aims to establish a national network for real-time monitoring of the quantity and quality of surface waterbodies, supported by IT applications for the management and dissemination of related information, as well as web services for various user groups (models for research and business application, forecasting systems, decision-making systems). Under this platform that focuses on inland water resources, existing measuring systems, currently operated by authorized organizations and individuals will be integrated, while new stations will be deployed by taking advantage of modern, low-cost data transfer technologies.

- Finally, conceptual, physical, or empirical hydrological and water quality modeling [100] or even alternative environmental modeling tools and new soft computing techniques based on artificial intelligence (e.g., artificial neural networks, adaptive neuro-fuzzy inference system, coupled wavelet and neural network, and conventional sediment rating curve approaches [101-106]), can be employed and integrated in the platform in the future for water quality forecasting and early warning system.

Supplementary Materials: The following are available online at http://www.mdpi.com/2073-4441/11/6/1310/s1, 54_RightsLink Printable License; 89_RightsLink Printable License. 
Author Contributions: Conceptualization, A.M., Y.P., and E.D.; Methodology, A.M., Y.P., and E.D.; Supervision, E.D.; Validation, A.M.; Visualization, A.M. and E.D.; Writing-original draft, A.M. and Y.P.; Writing-review \& editing, E.D.

Funding: This study was conducted under the first implementation phase (2018-2020) of the National Research Infrastructure (RI) "Hellenic Integrated Marine-Inland waters Observing Forecasting and offshore Technology System, HIMIOFoTS" (MIS 5002739), funded by Special Secretary for Management of European Regional Development Fund (ERDF) \& Cohesion Fund (CF).

Conflicts of Interest: The authors declare no conflicts of interest.

\section{References}

1. Mehta, L. Water and human development. World Dev. 2014, 59, 59-69. [CrossRef]

2. Dore, M.H. Global Drinking Water Management and Conservation; Springer International Publishing: Cham, Switzerland, 2015.

3. Boyd, C.E. Water Quality: An Introduction, 2nd ed.; Springer International Publishing: Cham, Switzerland, 2015.

4. Sadiq, R.; Haji, S.A.; Cool, G.; Rodriguez, M.J. Using penalty functions to evaluate aggregation models for environmental indices. J. Environ. Manag. 2010, 91, 706-716. [CrossRef]

5. Tyagi, S.; Sharma, B.; Singh, P.; Dobhal, R. Water Quality Assessment in Terms of Water Quality Index. Am. J. Water Resour. 2013, 1, 34-38.

6. Bharti, N.; Katyal, D. Water Quality Indices Used for Surface Water Vulnerability Assessment Water quality indices used for surface water vulnerability assessment. Int. J. Environ. Sci. 2011, 2, 154-173.

7. Plummer, R.; de Loë, R.; Armitage, D. A Systematic Review of Water Vulnerability Assessment Tools. Water Resour. Manag. 2012, 26, 4327-4346. [CrossRef]

8. Zhang, L.; Thomas, S.; Mitsch, W.J. Design of real-time and long-term hydrologic and water quality wetland monitoring stations in South Florida, USA. Ecol. Eng. 2017, 108, 446-455. [CrossRef]

9. Meyer, A.M.; Klein, C.; Fünfrocken, E.; Kautenburger, R.; Beck, H.P. Real-time monitoring of water quality to identify pollution pathways in small and middle scale rivers. Sci. Total Environ. 2019, 651, 2323-2333. [CrossRef]

10. Ockenden, M.C.; Deasy, C.E.; Benskin, C.M.W.H.; Beven, K.J.; Burke, S.; Collins, A.L.; Evans, R.; Falloon, P.D.; Forber, K.J.; Hiscock, K.M.; et al. Changing climate and nutrient transfers: Evidence from high temporal resolution concentration-flow dynamics in headwater catchments. Sci. Total Environ. 2016, 548, 325-339. [CrossRef]

11. Gujral, A.; Bhalla, A.; Biswas, D.K. Automatic water level and water quality monitoring. In Proceedings of the Ninth Symposium on Field Measurements in Geomechanics; Dight, P.M., Ed.; Australian Centre for Geomechanis: Perth, Australia, 2015; pp. 511-523.

12. Shore, M.; Murphy, S.; Mellander, P.E.; Shortle, G.; Melland, A.R.; Crockford, L.; O'Flaherty, V.; Williams, L.; Morgan, G.; Jordan, P. Influence of stormflow and baseflow phosphorus pressures on stream ecology in agricultural catchments. Sci. Total Environ. 2017, 590, 469-483. [CrossRef]

13. Bowes, M.J.; Loewenthal, M.; Read, D.S.; Hutchins, M.G.; Prudhomme, C.; Armstrong, L.K.; Harman, S.A.; Wickham, H.D.; Gozzard, E.; Carvalho, L. Identifying multiple stressor controls on phytoplankton dynamics in the River Thames (UK) using high-frequency water quality data. Sci. Total Environ. 2016, 569, 1489-1499. [CrossRef]

14. Strobl, R.O.; Robillard, P.D. Network design for water quality monitoring of surface freshwaters: A review. J. Environ. Manag. 2008, 87, 639-648. [CrossRef] [PubMed]

15. Altenburger, R.; Ait-Aissa, S.; Antczak, P.; Backhaus, T.; Barceló, D.; Seiler, T.B.; Brion, F.; Busch, W.; Chipman, K.; de Alda, M.L.; et al. Future water quality monitoring_Adapting tools to deal with mixtures of pollutants in water resource management. Sci. Total Environ. 2015, 512, 540-551. [CrossRef] [PubMed]

16. Eerkes-Medrano, D.; Thompson, R.C.; Aldridge, D.C. Microplastics in freshwater systems: A review of the emerging threats, identification of knowledge gaps and prioritisation of research needs. Water Res. 2015, 75, 63-82. [CrossRef] [PubMed]

17. Fölster, J.; Johnson, R.K.; Futter, M.N.; Wilander, A. The Swedish monitoring of surface waters: 50 years of adaptive monitoring. Ambio 2014, 43, 3-18. [CrossRef] [PubMed] 
18. Timmerman, J.G.; Beinat, E.; Termeer, K.; Cofino, W. Analyzing the data-rich-but-information-poor syndrome in dutch water management in historical perspective. Environ. Manag. 2010, 45, 1231-1242. [CrossRef] [PubMed]

19. European Commission European Commission Council. Directive 2000/60/EC of the European Parliament and of the Council of 23 October 2000 establishing a framework for Community action in the field of water policy. Off. J. Eur. Communities 2000, L327, 1-72.

20. Connon, R.E.; Geist, J.; Werner, I. Effect-based tools for monitoring and predicting the ecotoxicological effects of chemicals in the aquatic environment. Sensors 2012, 12, 12741-12771. [CrossRef]

21. Wernersson, A.S.; Carere, M.; Maggi, C.; Tusil, P.; Soldan, P.; James, A.; Sanchez, W.; Dulio, V.; Broeg, K.; Reifferscheid, G.; et al. The European technical report on aquatic effect-based monitoring tools under the water framework directive. Environ. Sci. Eur. 2015, 27, 7. [CrossRef]

22. Ritchie, J.C.; Zimba, P.V.; Everitt, J.H. Remote Sensing Techniques to Assess Water Quality. Photogramm. Eng. Remote Sens. 2013, 69, 695-704. [CrossRef]

23. Chocarro-Ruiz, B.; Fernández-Gavela, A.; Herranz, S.; Lechuga, L.M. Nanophotonic label-free biosensors for environmental monitoring. Curr. Opin. Biotechnol. 2017, 45, 175-183. [CrossRef]

24. Murphy, K.; Heery, B.; Sullivan, T.; Zhang, D.; Paludetti, L.; Lau, K.T.; Diamond, D.; O'Connor, N.; Costa, E.; Regan, F. A low-cost autonomous optical sensor for water quality monitoring. Talanta 2015, 132, 520-527. [CrossRef] [PubMed]

25. Winkelbauer, A.; Fuiko, R.; Krampe, J.; Winkler, S. Crucial elements and technical implementation of intelligent monitoring networks. Water Sci. Technol. 2014, 70, 1926-1933. [CrossRef] [PubMed]

26. World Meteorological Organization. Planning of Water Quality Monitoring Systems; Technical Report Series No. 3; World Meteorological Organization: Geneva, Switzerland, 2013.

27. Alilou, H.; Moghaddam Nia, A.; Keshtkar, H.; Han, D.; Bray, M. A cost-effective and efficient framework to determine water quality monitoring network locations. Sci. Total Environ. 2018, 624, 283-293. [CrossRef] [PubMed]

28. Chang, C.-L.; Lin, Y.-T. A water quality monitoring network design using fuzzy theory and multiple criteria analysis. Environ. Monit. Assess. 2014, 186, 6459-6469. [CrossRef] [PubMed]

29. Keum, J.; Kornelsen, K.; Leach, J.; Coulibaly, P. Entropy Applications to Water Monitoring Network Design: A Review. Entropy 2017, 19, 613. [CrossRef]

30. Khalil, B.; Ouarda, T.; St-Hilaire, A. A statistical approach for the assessment and redesign of the Nile Delta drainage system water-quality-monitoring locations. J. Environ. Monit. 2011, 13, 2190-2205. [CrossRef] [PubMed]

31. Noori, R.; Sabahi, M.S.; Karbassi, A.R.; Baghvand, A.; Zadeh, H.T. Multivariate statistical analysis of surface water quality based on correlations and variations in the data set. Desalination 2010, 260, 129-136. [CrossRef]

32. Ou, C.; St-Hilaire, A.; Ouarda, T.B.M.J.; Conly, F.M.; Armstrong, N.; Khalil, B.; Proulx-McInnis, S. Coupling geostatistical approaches with PCA and fuzzy optimal model (FOM) for the integrated assessment of sampling locations of water quality monitoring networks (WQMNs). J. Environ. Monit. 2012, 14, 3118-3128. [CrossRef] [PubMed]

33. Ouyang, Y. Evaluation of river water quality monitoring stations by principal component analysis. Water Res. 2005, 39, 2621-2635. [CrossRef]

34. Strobl, R.O.; Robillard, P.D.; Shannon, R.D.; Day, R.L.; McDonnell, A.J. A water quality monitoring network design methodology for the selection of critical sampling points: Part I. Environ. Monit. Assess. 2006, 112, 137-158. [CrossRef]

35. Behmel, S.; Damour, M.; Ludwig, R.; Rodriguez, M.J. Water quality monitoring strategies-A review and future perspectives. Sci. Total Environ. 2016, 571, 1312-1329. [CrossRef] [PubMed]

36. Ministry of Environment and Energy. Special Secretariat for Water National Water Monitoring Network. Available online: http://nmwn.ypeka.gr/?q=en (accessed on 1 May 2018).

37. European Commission. Report on the Progress in Implementation of the Water Framework Directive Programmes of Measures; European Commission: Brussels, Belgium, 2015.

38. Council of European Communities Council. Directiveof 12 December 1991 concerning the protection of waters against pollution caused by nitrates from agricultural sources. Off. J. Eur. Communities 1991, L375, 1-8.

39. Council of the European Union. Directive 2006/118/EC of the European Parliament and of the Council of 12 December 2006 on the protection of groundwater against pollution and deteriotation. Off. J. Eur. Union 2006, L118, 20. 
40. European Commission Council. Directive 2007/60/EC of the European Parliament and of the Council of 23 October 2007 on the assessment and management of flood risks. Off. J. Eur. Union 2007, L 288, 27-34.

41. Carvalho, L.; Mackay, E.B.; Cardoso, A.C.; Baattrup-Pedersen, A.; Birk, S.; Blackstock, K.L.; Borics, G.; Borja, A.; Feld, C.K.; Ferreira, M.T.; et al. Protecting and restoring Europe's waters: An analysis of the future development needs of the Water Framework Directive. Sci. Total Environ. 2019, 658, 1228-1238. [CrossRef] [PubMed]

42. Wong, B.P.; Kerkez, B. Real-time environmental sensor data: An application to water quality using web services. Environ. Model. Softw. 2016, 84, 505-517. [CrossRef]

43. Chen, Y.; Han, D. Water quality monitoring in smart city: A pilot project. Autom. Constr. 2018, 89, 307-316. [CrossRef]

44. Drobne, S.; Lisec, A. Multi-attribute Decision Analysis in GIS: Weighted Linear Combination and Ordered Weighted Averaging. Informatica 2009, 33, 459-474.

45. Malczewski, J.; Rinner, C. Introduction to GIS-MCDA. In Multicriteria Decision Analysis in Geographic Information Science. Advances in Geographic Information Science; Malczewski, J., Rinner, C., Eds.; Springer: Berlin/Heidelberg, Germany, 2015; pp. 23-54.

46. Zarghami, M.; Szidarovszky, F. Multicriteria Analysis. Applications to Water and Environment Management; Springer: Berlin/Heidelberg, Germany, 2011; Volume 67.

47. Malczewski, J. GIS and Multicriteria Decision Analysis; John Wiley \& Sons, Inc.: New York, NY, USA, 1999.

48. Malczewski, J. Local Weighted Linear Combination. Trans. GIS 2011, 15, 439-455. [CrossRef]

49. Malczewski, J. On the use of weighted linear combination method in GIS: Common and best practice approaches. Trans. GIS 2000, 4, 5-22. [CrossRef]

50. Voogd, J.H. Multicriteria Evaluation for Urban and Regional Planning; Delftsche Uitgevers Maatschappij: Delft, The Netherlands, 1982.

51. Saaty, T.L. A scaling method for priorities in hierarchical structures. J. Math. Psychol. 1977, 15, $234-281$. [CrossRef]

52. Goodwin, P.; Wright, G. Decision Analysis for Management Judgment; Wiley: Chichester, UK, 2004.

53. Saaty, T.L. Decision making with the analytic hierarchy process. Int. J. Serv. Sci. 2008, 1, 83-98. [CrossRef]

54. Saaty, T.L.; Vargas, L.G. Models, Methods, Concepts and Applications of the Analytic Hierarchy Process; Kluwer Academic Publishers: Dordrecht, The Netherlands, 2001.

55. Xu, L.; Zhang, Y. A Credit Rating Model for Online P2P Lending Based on Analytic Hierarchy Process. In Advances in Intelligent Systems and Computing, Proceedings of the Tenth International Conference on Management Science and Engineering Management, Baku, Azerbaijan, 30 August-2 September 2016; Xu, J., Hajiyev, A., Nickel, S., Gen, M., Eds.; Springer: Singapore, 2017; Volume 502, p. 502.

56. Saaty, T.L.; Vargas, L.G. Prediction, Projection and Forecasting; Kluwer Academic Publishers: Dordrecht, The Netherlands, 1991.

57. Marinoni, O. Implementation of the analytical hierarchy process with VBA in ArcGIS. Comput. Geosci. 2004, 30, 637-646. [CrossRef]

58. Skoulikidis, N.; Economou, A.; Gritzalis, K.; Zogaris, S. Rivers of the Balkans. In Rivers of Europe; Tockner, K., Uehlinger, U., Robinson, C.T., Eds.; Academic Press: London, UK, 2009.

59. Meybeck, M.; Friedrich, G.; Thomas, R.; Chapman, D. Rivers. In Water Quality Assessments-A Guide to Use of Biota, Sediments and Water in Environmental Monitoring; Chapman, D., Ed.; UNESCO/WHO/UNEP: London, UK, 1996.

60. European Environmental Agency-EEA. CORINE Land Cover. 2012. Available online: https://land.copernicus. eu/pan-european/corine-land-cover/clc-2012/view (accessed on 10 October 2016).

61. Dimitriou, E.; Mentzafou, A. Assessing the impacts of climate and land use changes on the water quality of a transboundary Balkan river. Water Air Soil Pollut. 2016, 227, 209. [CrossRef]

62. Hellenic Ministry of Economy \& Development-General Secretariat for Industry. GIS Decision Support System for Investors in Manufacturing. Available online: http://gis.ggb.gr/ioived/ (accessed on 1 May 2018).

63. Sophocleous, M. Interactions between groundwater and surface water: The state of the science. Hydrogeol. J. 2002, 10, 52-67. [CrossRef]

64. Ford, D.; Williams, P. Karst Hydrogeology and Geomprphology; John Wiley \& Sons Ltd.: Chichester, UK, 2007.

65. Kazakis, N.; Chalikakis, K.; Mazzilli, N.; Ollivier, C.; Manakos, A.; Voudouris, K. Management and research strategies of karst aquifers in Greece: Literature overview and exemplification based on hydrodynamic 
modelling and vulnerability assessment of a strategic karst aquifer. Sci. Total Environ. 2018, 643, 592-609. [CrossRef] [PubMed]

66. Ministry of Environment and Energy. Special Secretariat for Water River Basin Management Plans of Greece. Available online: http://wfdver.ypeka.gr/el/home-gr/ (accessed on 1 May 2018).

67. Pedrero, F.; Kalavrouziotis, I.; Alarcón, J.J.; Koukoulakis, P.; Asano, T. Use of treated municipal wastewater in irrigated agriculture-Review of some practices in Spain and Greece. Agric. Water Manag. 2010, 97, 1233-1241. [CrossRef]

68. Council of the European Union Counscil. Directive of 21 May 1991 concerning urban waste water treatment (91/271/EEC). Off. J. Eur. Communities 1991, L135, 40-52.

69. Ministry of Environment and Energy. Special Secretariat for Water Wastewater Treatment Plants Monitoring Database. Available online: http://astikalimata.ypeka.gr/Default.aspx (accessed on 1 May 2018).

70. Woodley, S.; Mackinnon, K.; Mccanny, S.; Pither, R.; Prior, K.; Salafsky, N.; Lindenmayer, D. Managing protected areas for biological diversity and ecosystem functions. In Protected Area Governance and Management; Worboys, G.L., Lockwood, M., Kothari, A., Feary, S., Pulsford, I., Eds.; ANU Press: Canberra, Australia, 2015; pp. 651-684.

71. European Environment Agency. Nationally Designated Areas (CDDA). Available online: http://cdr.eionet. europa.eu/gr/eea/cdda1 (accessed on 1 May 2018).

72. Sinokrot, B.A.; Gulliver, J.S. In-stream flow impact on river water temperatures. J. Hydraul. Res. 2000, 38, 339-349. [CrossRef]

73. Avilés, A.; Niell, F.X. The control of a small dam in nutrient inputs to a hypertrophic estuary in a Mediterranean climate. Water. Air. Soil Pollut. 2007, 180, 97-108. [CrossRef]

74. Vitor Cortes, R.M.; Ferreira, M.T.; Oliveira, S.V.; Godinho, F.; Manuel, R.; Cortes, V. Contrasting impact of small dams on the macroinvertebrates of two Iberian mountain rivers. Hydrobiologia 1998, 389, 51-61. [CrossRef]

75. Aristi, I.; Arroita, M.; Larrañaga, A.; Ponsatí, L.; Sabater, S.; von Schiller, D.; Elosegi, A.; Acuña, V. Flow regulation by dams affects ecosystem metabolism in Mediterranean rivers. Freshw. Biol. 2014, 59, 1816-1829. [CrossRef]

76. Milliman, J.D.; Farnsworth, K.L. Human activities and their impacts. In River Discharge to the Coastal Ocean: A Global Synthesis; Milliman, J.D., Farnsworth, K.L., Eds.; Cambridge University Press: Cambridge, UK, 2011; pp. 115-164.

77. ICOLD. Constitution Status; ICOLD: Paris, France, 2011.

78. Generation of electricity from renewable energy sources and through high-efficiency co-generation of electricity and heat and miscellaneous provisions (Law 3468/2006). Off. J. Hell. Repub. 2006, 129, 1405-1426.

79. Biggs, J.; Williams, P.; Whitfield, M.; Nicolet, P.; Weatherby, A. 15 Years of pond assessment in Britain: Results and lessons learned from the work of Pond Conservation. Aquat. Conserv. Mar. Freshw. Ecosyst. 2005, 15, 693-714. [CrossRef]

80. Williams, P.; Biggs, J.; Crowe, A.; Murphy, J.; Nicolet, P.; Weatherby, A.; Dunbar, M. Countryside Survey: Ponds Report from 2007; CS Technical Report No. 7/07, CEH Project Number: C03259; NERC/Centre for Ecology \& Hydrology: Lancaster, UK, 2010; 77p.

81. Ministry of Rural Development and Food of Greece. Dams and Artifical Reservoirs of Ministry of Rural Development and Food; Ministry of Rural Development and Food of Greece: Athens, Greece, 2006.

82. Greek Committee on Large Dams. The Dams of Greece; Greek Committee on Large Dams: Athens, Greece, 2013.

83. Ministry of Rural Development and Food of Greece Land Reclamation Projects and Exploitation of Soil-Water Resources. Available online: http:/www.minagric.gr/index.php/el/for-farmer-2/eggeiesbeltioseis/ sxedismowee/963-sxediasmoskaiparakeggergon (accessed on 1 May 2018).

84. Regulatory Authority for Energy of Greece Regulatory Authority for Energy-Geoinformation Map. Available online: http://www.rae.gr/geo/ (accessed on 1 May 2018).

85. European Environmental Agency-EEA. European Catchments and Rivers Network System-ECRINS. Available online: https://www.eea.europa.eu/data-and-maps/data/european-catchments-and-riversnetwork\#tab-figures-produced (accessed on 17 March 2016).

86. Hamza, S.M.; Ahsan, A.; Imteaz, M.A.; Rahman, A.; Mohammad, T.A.; Ghazali, A.H. Accomplishment and subjectivity of GIS-based DRASTIC groundwater vulnerability assessment method: A review. Environ. Earth Sci. 2015, 73, 3063-3076. [CrossRef]

87. Tehrany, M.S.; Pradhan, B.; Jebur, M.N. Flood susceptibility mapping using a novel ensemble weights-of-evidence and support vector machine models in GIS. J. Hydrol. 2014, 512, 332-343. [CrossRef] 
88. HCMR. Monitoring of the Ecological Water Quality of Rivers, Coastal and Transitional Waters of Greece to Implement the Article 8 of Water Framework Directive 2000/60/EC; Ministry of Environment and Energy, Special Secretariat of Water: Anavyssos, Greece, 2016.

89. Skoulikidis, N.T.; Amaxidis, Y.; Bertahas, I.; Laschou, S.; Gritzalis, K. Analysis of factors driving stream water composition and synthesis of management tools-A case study on small/medium Greek catchments. Sci. Total Environ. 2006, 362, 205-241. [CrossRef]

90. Cardoso, A.C.; Duchemin, J.; Magoarou, P.; Premazzi, G. Criteria for the Identification of Freshwaters Subject to Eutrophication, EUR 19810 EN; EC Joint Research Centre: Ispra, Italy, 2001.

91. Skoulikidis, N.; Dimitriou, E.; Karaouzas, I. The Rivers of Greece; Springer: Berlin/Heidelberg, Germany, 2018.

92. Khalil, B.; Ouarda, T.B.M.J.; St-Hilaire, A.; Chebana, F. A statistical approach for the rationalization of water quality indicators in surface water quality monitoring networks. J. Hydrol. 2010, 386, 173-185. [CrossRef]

93. Pinto, U.; Maheshwari, B.L. River health assessment in peri-urban landscapes: An application of multivariate analysis to identify the key variables. Water Res. 2011, 45, 3915-3924. [CrossRef]

94. Chen, Q.; Wu, W.; Blanckaert, K.; Ma, J.; Huang, G. Optimization of water quality monitoring network in a large river by combining measurements, a numerical model and matter-element analyses. J. Environ. Manag. 2012, 110, 116-124. [CrossRef]

95. Do, H.T.; Lo, S.L.; Chiueh, P.T.; Phan Thi, L.A. Design of sampling locations for mountainous river monitoring. Environ. Model. Softw. 2012, 27, 62-70. [CrossRef]

96. Liyanage, C.P.; Marasinghe, A.; Yamada, K. Comparison of Optimized Selection Methods of Sampling Sites Network for Water Quality Monitoring in a River. Int. J. Affect. Eng. 2016, 15, 195-204. [CrossRef]

97. Mariotti, A.; Struglia, M.V.; Zeng, N.; Lau, K.-M. The hydrological cycle in the Mediterranean region and implications for the water budget of the Mediterranean Sea. J. Clim. 2002, 15, 1674-1690. [CrossRef]

98. Skoulikidis, N.T. The environmental state of rivers in the Balkans-A review within the DPSIR framework. Sci. Total Environ. 2009, 407, 2501-2516. [CrossRef] [PubMed]

99. Panagopoulos, Y.; Makropoulos, C.; Kossida, M.; Mimikou, M. Optimal Implementation of Irrigation Practices: Cost-Effective Desertification Action Plan for the Pinios Basin. J. Water Resour. Plan. Manag. 2014, 140, 05014005. [CrossRef]

100. Tsakiris, G.; Alexakis, D. Water quality models: An overview. Eur. Water 2012, 37, 33-46.

101. Alizadeh, M.J.; Jafari Nodoushan, E.; Kalarestaghi, N.; Chau, K.W. Toward multi-day-ahead forecasting of suspended sediment concentration using ensemble models. Environ. Sci. Pollut. Res. 2017, 24, 28017-28025. [CrossRef]

102. Alizadeh, M.J.; Kavianpour, M.R.; Danesh, M.; Adolf, J.; Shamshirband, S.; Chau, K.W. Effect of river flow on the quality of estuarine and coastal waters using machine learning models. Eng. Appl. Comput. Fluid Mech. 2018, 12, 810-823. [CrossRef]

103. Chen, X.Y.; Chau, K.W. A Hybrid Double Feedforward Neural Network for Suspended Sediment Load Estimation. Water Resour. Manag. 2016, 30, 2179-2194. [CrossRef]

104. Olyaie, E.; Banejad, H.; Chau, K.W.; Melesse, A.M. A comparison of various artificial intelligence approaches performance for estimating suspended sediment load of river systems: A case study in United States. Environ. Monit. Assess. 2015, 187, 189. [CrossRef]

105. Shamshirband, S.; Jafari Nodoushan, E.; Adolf, J.E.; Abdul Manaf, A.; Mosavi, A.; Chau, K. Ensemble models with uncertainty analysis for multi-day ahead forecasting of chlorophyll a concentration in coastal waters. Eng. Appl. Comput. Fluid Mech. 2018, 13, 91-101. [CrossRef]

106. Wang, W.C.; Xu, D.M.; Chau, K.W.; Lei, G.J. Assessment of river water quality based on theory of variable Fuzzy sets and Fuzzy Binary comparison method. Water Resour. Manag. 2014, 28, 4183-4200. [CrossRef]

(C) 2019 by the authors. Licensee MDPI, Basel, Switzerland. This article is an open access article distributed under the terms and conditions of the Creative Commons Attribution (CC BY) license (http://creativecommons.org/licenses/by/4.0/). 